\title{
Writing Victimhood
}

\section{A methodological manifesto for researching digital sexual assault}

\section{By Signe Uldbjerg}

\begin{abstract}
Non-consensual sharing of intimate images, here called digital sexual assault (DSA), has been a heavily debated subject in Denmark over the past few years. In the polarized public and academic debate, DSA victims are often either subjected to victim blaming or portrayed as 'broken' victims with little agency and hope of redemption. This article presents a methodology for working with DSA victims to construct their own alternative and empowering stories of victimhood.

Through an experimental methodology based on creative writing, I have included three young women in a process of collectively developing and exploring aspects of their experiences with DSA. With this methodology, I aim to combine activism and research in investigating DSA and actively supporting victims in constructing progressive stories of victimhood; stories that, as activism, work in opposition to oppressive discourses, and, as research, offer insights into complex experiences of victimhood. The article ends in a discussion of change as the prospect of activist research and experimental methodologies and concludes with a "manifesto for writing victimhood" stating activist aims that encourage and value social, personal and political change in and through research.
\end{abstract}

KEYWORDS: Digital sexual assault, image-based sexual abuse, victimization, activism, methods, ethics. 
"She can never have a normal life"

Ole Søgaard-Nielsen in Jensen and Ilsøe (2018)

"They have nothing to lose anymore. They have lost their name and reputation"

Miriam Michaelsen in Vestergaard and Jensen (2019)

These quotes are from prominent lawyers and advocates representing victims of non-consensual, sexual image sharing. They are part of a debate about digital sexual assault (otherwise known as image-based sexual abuse) that has been gaining recent attention. Since Emma Holten (2014), the first person in Denmark to become well-known after going public, published her story, there has regularly been new cases of digital sexual assault (DSA) surfacing in the national press. During this time, DSA has been an ideological and political battlefield. On one side, there are those who describe it as a problem mainly concerning young people's risky digital behaviour with child psychologist John Hasle being a prominent example:

"They should not be sharing anything. [...] we must tell them that we don't feel sorry for them when their nude images have been shared - because we told them what consequences it [taking them ed.] could have." (Sommerand, 2017)

On the other side are lawyers, activists and NGOs advocating for policies that take DSA seriously. The introductory quotes are examples of how they often frame the consequences of DSA. While there are other perspectives present in the public debate, e.g. those of educators and teachers, it often tends to be polarized between victim blaming and stories of ruined lives. Hence, victims are mainly offered two possible positions: Either they are seen as reckless, naïve teenagers and their victimhood unacknowledged, or they are seen as inherently damaged by the assault and thus deprived of agency in creating better futures for themselves.

The public visibility of this debate has affected academic interests as well. It is a common argument among scholars researching intimate digital practises that the victims' side has already been heard. For example, in a recent special issue of MedieKultur that focussed on digital intimacies, several articles unfold the argument that assault has dominated the debate on digital sexual practises so that other studies are now needed (Thorhauge, Demant, \& Krogager, 2020). Ironically, none of them reference studies that present the side of victims through their own words.

While I certainly agree that multi-facetted knowledge of intimate sharing practises is important, I also think that the perspectives of victims have not yet been, and need to be, heard. Therefore, I wanted to explore alternative positions of victimhood, or rather, I wanted to build a research project that could support victims in developing and exploring such stories themselves. This article presents the methodological efforts behind this aim; I am not so much analysing victim positions as I am evaluating the methodological basis for their construction.

As an activist, I have met a large number of women who are living with the consequences of sexual assault, and I live with such experiences myself. I know how frustrating and painful it can be to find yourself stuck in a position where you have to choose between giving up your claim to victimhood and accepting the stigma of the 'ruined' victim. Therefore, I recognize the importance and vulnerability of negotiating victim-positions, and these negotiations are what current research on DSA 
overlooks. This is also why, I hold on to victim instead of e.g. survivor; I wish to insist on victimhood as a position of authority, one that gives you a special insight when addressing sexual assault personally and politically. Further, the participants of this study openly preferred victim, referring to the term 'survivor' as something 'American' (and alienating) or not descriptive of assaults that essentially repeat themselves every time the images are shared.

The three women, who became my co-researchers and co-activists in this project, choose the pseudonyms Mathilde, Karen and Amalie; these names are references to historic Danish female writers (Mathilde Fibiger, Karen Blixen and Amalie Skram), and they thereby echo a history of women claiming a voice through writing. And writing, as the title indicates, was our methodological practise. In the participatory setting of the writing workshop, we used creative writing as a method for collectively developing a language to describe experiences of DSA different from those dominant stories mentioned above. The methodology does not assume that alternative stories of DSA victimhood already exist if we look the right places. Rather, it seeks to construct new and complex stories; stories with empowering and thus political potentials.

This article examines the possibilities and dilemmas of this methodology. First, I define a set of theoretical principles for doing feminist activist research. Elaborating on these principles takes me through the methodological and ethical reflections behind the project. The section 'Activist research must engage in problem-solving' suggests experimental and creative methods as a way to accommodate the need for more nuanced stories of DSA victimhood. The following two sections analyse ethical challenges inherent in this approach, and the next section discusses these ethical considerations in relation to victimhood specifically. The final session concludes by addressing the hope for change as basis for the above considerations and by proposing a "manifesto for writing victimhood" placing the research project in the context of a collective activist struggle.

In short, the article offers some answers to the complex question of how to do ethical and activist research on a highly sensitive subject that, like sexual violence in the context of MeToo, is vibrant with public opinion.

\section{Activist research}

By activist research, I mean a method through which we affirm a political alignment with an organized group of people in struggle and allow dialogue with them to shape each phase of the process (97)

These are the words of Charles Hale (2006) when reflecting on his own activist research practices. In his approach, inclusion is the key to doing activist research that represents oppressed perspectives respectfully and within their own regimes of truth rather than those of the stigmatizing majority. This logic is rooted in the idea that the victims of a specific struggle cannot only learn to understand their problems but also to provide sustainable solutions (Koirala-Azad \& Fuentes, 2009). Therefore, the alignment that Hale mentions is crucial for activist research that seeks to pose realistic and viable solutions to social problems. Activist research, in other words, must be participatory.

Along similar lines, activist research must seek to engage in problem-solving. Reason and Bradbury (2008) argue that the strength of activist research is its ability to find social and political solutions based on knowledge and reflection. "Action without reflection and understanding is blind, just as theory without action is meaningless" (4), they state, calling for researchers to use theory for the purpose of action.

Addressing structural inequality, the proposed solutions must move beyond the individual to the collective level. Nancy Naples (2003) makes this point when discussing the potentials of individual victim stories as part of a joined struggle. While Naples argues that coming forward with individual stories of assault can be empowering and serve as a way to raise a feminist movement, she criticizes discourses that are either dominated by expert statements and ignore the voices of victims or become spectacles of individualized 
pain without exposing the underlying, structural inequalities. Activist research must be collective.

However, engaging in collective, political struggles blurs the relation between the researcher, the researched and the research (Naples, 2003). Politics and research become inseparable and pose what Hale (2006) calls "dual loyalties" referring to how activist scholars "must embrace two quite distinct sets of objectives and forms of accountability, and they must negotiate the often considerable tensions between them" (105). These tensions, between academic norms of accountability and activist goals of political and personal change, result in activist research being evaluated on two different parameters: The researcher is accountable for the quality and reliability of the research and for its social and political impacts. Thus, activist research poses dual commitments.

A commitment that lies in the tension between activism and research is representation. How is it possible to represent victims respectfully within a research culture that has a history of objectifying women and minorities for the sake of the development of that very knowledge system (Naples, 2003)? One answer to this challenge, echoed in many works on feminist research, is the argument that empathy supports representation. Within participatory action research, Reid and Frisby (2008) advocate for empathetic dialogue as a method that encourages diversity because listening to others is the basis for understanding and representing their unique perspectives. The same idea is prevalent in the field of feminist care ethics; Carol Gilligan (2014) writes:

[W] need to hear and encourage the full range of voices within and around us by becoming a society of listeners. Active listening means asking, how might I call forth a voice that is held in silence, a voice under political or religious or psychological constraint? (104)

Gilligan's work originally criticized a research culture that did not represent women and girls. She posed a feminist ethics based on listening and care as a way to encourage diversity and aim for representation (Gilligan, 1982). The idea of thinking with care as an ethical principle has developed into a broad field of feminist care ethics emphasizing the importance of relational obligations in research (Bellacasa, 2017; Held, 2014; Tronto, 1994). Hence, activist research aims for representation through care.

Finally, activist research provides hope, or in the words of Koirala-Azad and Fuentes (2009) it "provides a hope for change that traditional research and scholarship often lack" (2). This is, I suggest, the essence of activist research; it allows us to hope for, believe in and work towards change.

Activist research must be participatory. Activist research must engage in problem-solving. Activist research must be collective. Activist research pose dual commitments. Activist research aims for representation through care. Activist research provides hope. These statements structure the following reflections on methodology and ethics. Returning to the subject of working with DSA victims, I will elaborate on the impacts of these principles when balancing research and activism.

\section{Activist research must engage in problem-solving}

As described in the introduction, a problem that DSA victims face is the lack of available positions that both offer agency and acknowledge victimhood. This project's commitment to problem-solving therefore lies in constructing alternative knowledge on DSA victimhood. An aim such as this calls for a methodological framework that pays attention to the performative aspects of research methods and their ability to not just investigate but also create. Lisa Blackman (2012) points to how performative methodological experiments can bring "something into being that did not preexist the experimental encounter" (184). Likewise, others argue that experimental methodologies can help us imagine alternative futures and open up for unrealized potentials of action and understanding (Davies, 2014; Lezaun, Marres, \& Tironi, 2016; Staunæs, 2016; Staunæs \& Kofoed, 2015b). 
An experiment, however, must be performed through specific practises. Sophie Hope (2016), working with what she terms practise research, elaborates on the intersections between creative practises and research. She distinguishes between research into practise, research that uses creative practises as methods and research that develops creative practises. In this case, the goal is to develop empowering practices among DSA victims through writing while these writing practices are also the method used to examine experiences of victimhood; this positions my methodology in the field between research through practise and research for practise. Research through practise shares traits with experimental methods as it emphasizes research as a constructive process. I would argue that in order to do an experiment, you need to build from a practise; here, writing is that practise.
Building on this tradition, I have designed a research process that functions as an experimental space fostering alternative knowledge production through collective and individual storytelling. This took place in four creative writing workshops, through continuous communication and finally follow-up interviews after the bulk of the research process was over. The figure illustrates this process.

In terms of data, this resulted in 23 creative writing texts and 105 pages of transcribed conversations and interviews. Out of the 23 texts, 11 were about DSA while the remaining texts were writing exercises with a pedagogical rather than empirical purpose. The first workshop started with an introduction to the research process and unstructured conversation, and at the end of the workshop, I introduced the first writing task. In workshops 2

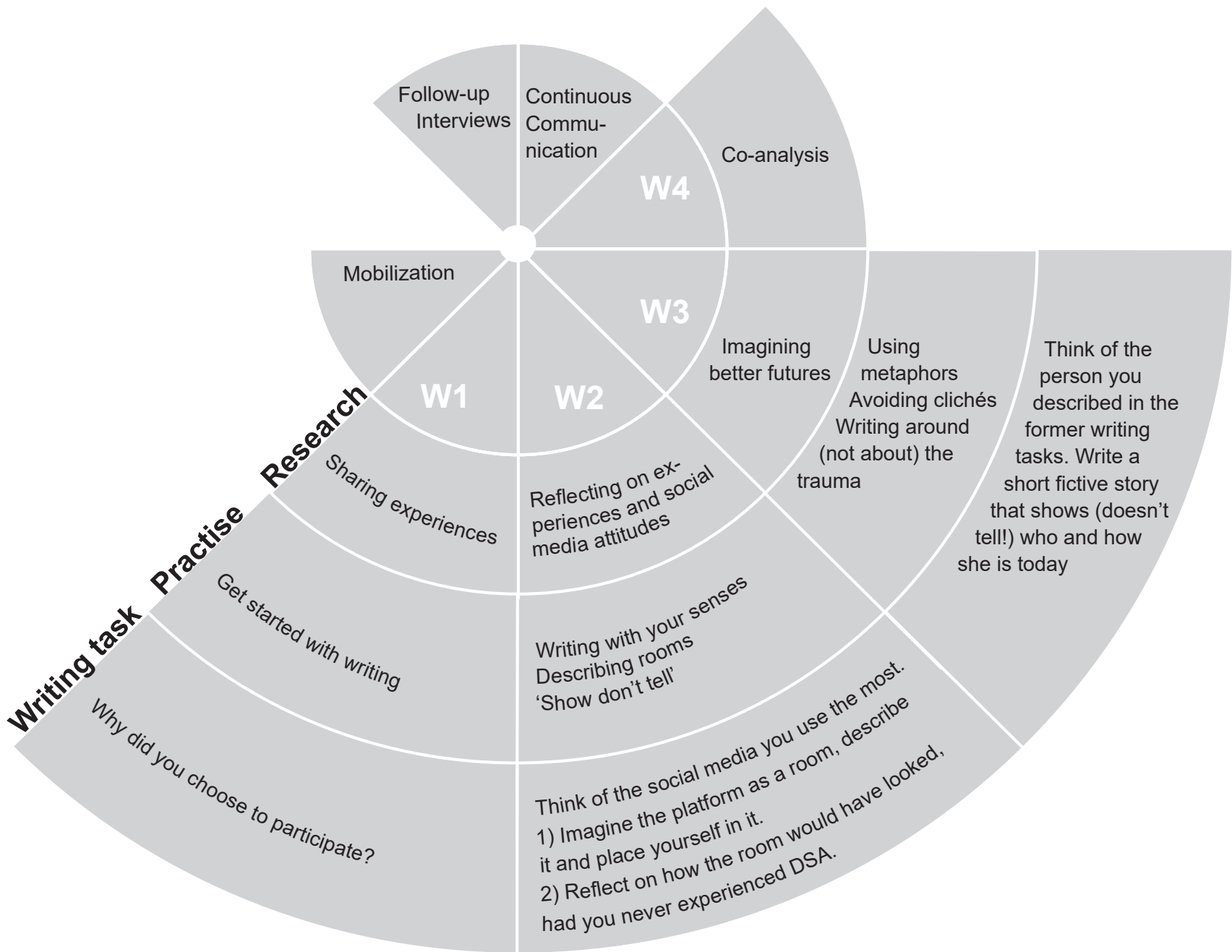

Figure 1: Research process 
and 3 , we first discussed the texts from the former workshops, then practiced writing and finally prepared for the next writing task. Workshop 4 started with sharing writing as well but was mostly spend on coding and analysing texts and transcriptions from the former workshops.

As indicated in the figure, each of the workshops had specific focus areas in relation to the research questions and the writing practise. The focus areas were combined in the main writing tasks, which draw on primarily two approaches to writing: Creative writing, as practised at Danish author schools, and therapeutic writing.

Therapeutic writing concerns caring for the participants, which I will return to in the following section. The creative writing approach offers the collective writing and reading workshop as a practise. These workshops consist of writing and reading texts to one another and collectively analysing and improving your writing (Lind, 2019). Creative writing offers both a method for working with writing in groups and a set of tools for designing and giving feedback on writing tasks that teach the participants a specific way of using language. Creative writing practitioners make it a point that writing is a way to see the world from new perspectives and gain new understandings through the creative breaking up and reshaping of everyday language (Llambías, 2015; Zola Christensen, 2005).

Altogether, experimental research can accommodate activist commitments to problem-solving in relation to DSA because research experiments can meet the needs of victims to construct alternative and oppositional truths. Having stated this connection between activist aims and research methods, in this case creative writing, I will now turn to the ethical dilemmas it implies.

\section{Activist research poses plural commitments}

While creative writing and experimental methods celebrate going beyond the well-known, they do not address the vulnerability of insisting on alternative truths. They pay little attention to the fact that staying within the normative often feels safer, even when this normative is as restraining as the narrow victim positions criticized here. This ethical concern goes beyond the dual loyalties between activism and research. Therefore, I wish to expand Hale's (2006) concept and instead talk about a plurality of commitments.

Phelan and Kinsella (2013), in their work on doing research with children, identify three ethical commitments that they name care, clarity and representation. Care is the here and now concern for the participants' well-being, clarity is the commitment to produce long-term beneficial knowledge, and representation is the obligation to represent the participants rightfully. Similar ideas are expressed by Staunæs and Kofoed (2015a) as the dilemma between long-term benefits and doing good here and now. They, in different ways, deal with the dilemmas between constructing good and useful knowledge and not sacrificing the participants' safety and dignity along the way. When combining these approaches with Hale's concept of dual commitment, three related categories of commitments appear:

1. The commitment to research clarity

2. The commitment to care

3. The commitment to activism, representation and change

In the above and following parts of this article, research and activism are the focus areas, but addressing vulnerabilities and care is important in order to understand the ethical complexity and precariousness of the process. I have no training in psychology or therapy, and I therefore needed an applicable way to minimize the risk of inflicting harm in the form of re-traumatization. Therapeutic writing offered a way to integrate precautions around care into the practise of my methodology.

There are different arguments within the field of therapeutic writing as to what writing and reading do. Some argue that the therapeutic potential in writing comes with gaining new perspectives through aesthetic engagement (Llambías, 2017; Steenberg \& Ladegaard, 2017; Zwisler et al., 2017); 
in this tradition, it is not important what people write about, but rather how they use writing to see the world in new ways. Others accredit the therapeutic potentials to finding new ways of reflecting on one's self and creating meaningful life narratives (Bolton, 2008; McNichol, 2016; Pennebaker, 1990); within this tradition, people are encouraged to write about themselves, and what they write is just as important as how they do it. Despite their differences, practitioners generally agree that the benefits of writing come from being confronted with something new and different, whether this is aesthetic forms and world-views or new perspectives on one's own story and thoughts. Not unlike creative writing, therapeutic writing seeks the potential of alternative truth in creative expression. McNichol (2016) specifically warns against writing processes that cause people to linger in their pain. She breaks the therapeutic writing process down into steps going from describing a trauma, to reflecting on it and finally moving on to write a new less restraining story. This process was incorporated into the progress of the writing tasks (see figure1).

The methodological approaches that I have drawn on all share a belief in the positive forces of the creative, as a way to gain new perspectives and develop alternative knowledge, and the new, as a way to heal trauma and change perceptions. But a dilemma that has haunted my conscience is on how to deal with the pieces of writing that are not 'good writing', in accordance with the creative writing principles, and do not tell alternative stories but instead dip into the usual, restraining discourses of DSA victimhood. Especially one text, by Karen, has troubled me:

She is vulnerable and a total security addict. When she has nightmares, hold her, be there for her [...] She is convinced that she is difficult to love because of the things she has been through. She is so atrociously strong that it is indescribable. Show her that she is not difficult to love, and let her never believe she is.

Be her rock through thick and thin.

Promise never to break her heart.
The text mirrors the story of broken lives surrounding DSA victims, and it draws on common figures indicating vulnerable girlhood. With this text, she paints a rather stereotypical picture of the vulnerable young girl in need of (male) care and protection. From an activist perspective, I have two concerns with this: First, it reinforces a gender pattern where women and girls are less in control of their own well-being and need a romantic connection to be safe. Second, it talks into the prejudices of DSA being mainly a problem concerning young, naïve girls with unrealistic romantic ideas. On the other side, I also see potential in openly sharing the voices of vulnerable girls and young women in a call for the world to take their lives and problems seriously. Several studies point to how the choices of girls are not taken seriously or even deemed risky, e.g. in relation to education and social lives (Driscoll, 2016), sexual expression (Lamb \& Peterson, 2012), and cultural practices (Hickey-Moody, 2013). From a feminist perspective, this needs to change.

However, I also have to consider if it is responsible to make Karen a scapegoat for this political agenda; after all, she contributed to the project wanting to shed light on DSA experiences, and defending girl culture is my agenda - not hers. Using her story as an example of this might, if read by the wrong audience, undermine her authority and make the stigma of naïve girlhood stick to her.

While I do not want to share a text that can expose or even ridicule Karen, and potentially contribute to a discourse that dismisses the importance of DSA as a 'girls-problem', I find the text analytically interesting. Put in contrast to Karen's other contributions, it points to how complicated assault experiences can be on one side needing to break out of limiting positions and on the other side finding comfort within them. Karen otherwise comes across as an incredibly strong victim. She is fighting for her case in the court and on a number of public platforms, and I need to accept that she wanted to show an aspect of her experience that does not match my ideology or her public 'mask', as she called it.

Negotiating this illustrates the dilemmas of plural commitments between research, care and 
representation. Even when integrating methods that encourage alternative stories and take precautions around care, ethical dilemmas like these arise when activist and methodological agendas meet people in their complex realities. The ethical challenges of bridging the personal and the political are the focus of the next section.

\section{Activist research must be participatory and collective}

Looking back at the workshop process a year later, Mathilde noted, "It is nice to see that it can be used for something real, for change". I asked her how she felt that she had contributed to this change, and after a moment of thinking in silence, she answered:

"With experiences. Not a lot of people had come forward with it at that time [...] If people don't understand how it affects you, it is difficult to offer specific help and to know what kinds of efforts are needed."

With this reflection, Mathilde places individual stories at the core of inflicting social and political change. Elaborating on the role of personal stories in political struggles, Nancy Naples (2003) writes:

Feminist allies must continue to recognize the value of speaking out and of personal testimony by survivors for processes of personal empowerment. Personal empowerment is the necessary stepping stone toward building a more inclusive movement. (185)

By pointing to personal empowerment as stepping stones, she connects the individual experience of claiming your own story with a political potential of creating a collective movement. In her account, the shift from individual pain to collective meaning making is essential to political processes, hence, the potential of individual assault stories in activism and research is their ability to expose the underlying, sexist or violent discourses by which these experiences are structured.
Naples also emphasizes the need for progressive discourses to come from victims themselves stating that victims must be "authors of their own lives" for their stories to stand "in opposition to oppressive expert discourse" (185). There are weaknesses in this notion since not all victims of sexual assault draw on oppositional discourses to frame their experiences, as Karen's example from above illustrates. However, there is something essential in the idea that a movement capable of inflicting change must be inclusive in the sense of listening to personal victim stories as a basis for collective political struggle. Letting victims define the essence of their struggle and the use of their stories is a participatory approach.

Participatory research overlaps with activist research as they both seek to include the subjects of the research into the research process. However, while participatory research often aims for total inclusion and research processes lead and designed by the participants from start till end (Bell et al., 2004; Bergold \& Thomas, 2012), activist research allows more researcher structured processes facing the challenge that participatory ideals are often compromised in practise (Borg, Karlsson, Kim, \& McCormack, 2012).

As this project evolves around storytelling, I have aimed to support the participants in defining which stories should be the outcomes and prospects of the research process. I offered the workshop as a space and writing as a practise, but the participants decided what to bring to that space, how to interpret it and often how to assess its values. In other words, within the experimental workshop space, they played the role of co-researchers as well. This convergence of perspectives (Bergold \& Thomas, 2012) took place as the participants started to see themselves as not just informants but co-researchers and activists contributing to research in the pursue of social and political change. Amalie addressed this position when stating that "knowledge is power, and the better we are at knowing and documenting the devastating consequences of digital sexual assault for the victims, the better we can get at making a difference." Here, she writes from a position of a 'we' that is both politically motivated 
and is in a position to create reliable and powerful knowledge, which is by essence the position of a researcher (Naples, 2003).

Amalie even addressed how working with writing as a medium of expression had given her a feeling of being in control of her own story. She puts this experience in opposition to contributing to news articles, saying, "I don't think your experiences are actually really being heard. It is more like they just want some sort of quote that they can use in an article".

There is irony to using a quote like that here - in an article. With this statement, Amalie criticizes the press as institutions that put the economic value of the good story over listening to victims. A similar dilemma is prevalent in participatory processes within the context of academic institutions; after all, these institutions have had enormous power in shaping the status quo of our knowledge systems. Further, institutional interests easily become built into the participants' perspectives (Mosse, 2001); when they start to see themselves as co-researchers they gain greater influence on the project, but they also accept the interests of the institution and the premise that academic knowledge is indeed important to political change.

In this way, ethical participation involves balancing between integrating participants into institutions that can legitimize and support their political aims, and the institution's interests in e.g. exploiting the stories of the vulnerable or strengthening their own claim to truth.

\section{Activist research aims for representation through care}

Now, I have elaborated on ethical tensions between care, clarity and representation, and I have considered the ethics of participation in relation to political movements and representation. Here, I wish to discuss these ethical dilemmas in relation to victimhood specifically.

Colvin (2019), working with victimhood in post-apartheid South Africa, shows how a strong belief in the power of victim stories can create reconciled victims who loose political agency because their trauma is considered healed as soon as their story is told. Similarly, Naples (2003) warns against a depoliticization of victimhood through individualization. Others, considering the wellbeing of the victim, points to how self-absorbent stories of victimhood can be harmful (McNichol, 2016; Pennebaker, 1990), or how the stigma of victimhood can marginalize people in their communities (Søndergaard, 2008). What they all warn against are positions of victimhood where the victims loose personal and political agency.

As stated in the section on activist research, care ethics address the challenge of managing representation without objectification. Feminist care ethics has been framed as a practice of listening to and encouraging unheard voices (Gilligan, 2014), a moral theory of respectfully meeting the needs of others (Held, 2014), an ethical practice of negotiating and criticising power structures (Tronto, 1994) and an approach to understanding the relational structures of co-dependence and power in human and non-human relations (Bellacasa, 2017). All these approaches share an awareness of the ways researcher and researched are entangled in relational structures of dependence. With an understanding of relations of care, it becomes clear how timid this research process is when seeking to include a group of people who are in need of care and representation but are also particularly vulnerable to objectification through the potential stigmas of victimhood.

One approach to this challenge is to listen to the needs of others as they appear in each unique context of relations. Amalie, for example, was at times very clear about what kind of care she was willing to accept. She insisted on being acknowledged as a victim in the justice system while also resisting others' encouragements to make her story into a spectacle of pain. She said:

"I think it is important to tell your story. But it was also because I wanted to tell it from a different perspective than just 'it is really hard'. [...] I didn't want to talk about how I felt, only about how I had been treated by the public institutions that I had contacted." 
Here, she points to how talking as a victim should allow you to criticize a system unfit to handle DSA related crimes. "I think being victimized by some things make you see a lot of stuff in society that is just fucking unfair," she adds arguing for a position of victimhood that gives social authority in addressing the struggles of DSA victims.

This shows how Amalie negotiates the idea of victimhood and allows it to frame aspects of her experiences while still resisting the misunderstood notions of care attached to the story of the 'ruined' victim. Listening to her story means understanding it as an emergent construction rather than fitting it into recognizable tales of victim-/survivor-hood. In this kind of listening, what Davies (2014) terms emergent listening, lies the potential of change. According to Davies, change becomes possible exactly when we stop listening for stories that confirm the status quo - the victim positions that we already know - and start listening for the possibility of the new. When we do so, victimhood with agency and without stigmatization becomes possible.

\section{Activist research provides hope}

Since DSA is a publicly debated subject, representation and diverse victim stories are central to shaping general opinions and allowing victims to exist on their own terms. I have argued that creative and experimental research methods are ways that research can support activist aims of broader representation by creating alternative knowledge. Alternative knowledge is central because one of the problems that DSA victims face is a lack of resources for shaping their own positions of victimhood personally and politically.

However, there are ethical challenges in taking on a political commitment to problem solving. I have discussed the plural commitments and potential dilemmas between caring for participants, producing useful data and meeting activist aims of representation and change. Similarly, I discussed some of the ethical challenges of balancing between participation as a necessity for knowledge production that inflict positive change, and participation as a gateway to exploiting the tragedies of the vulnerable or strengthening potentially oppressive institutions.

Finally, I discussed representation through care as an approach to balancing these ethical dilemmas by listening to victims and allowing them to define their own victimhood. I argued that these methods and ethical considerations are necessary for facilitating emergent listening and making it possible to construct alternative victim positions with agency and without stigmatization.

The article has presented a mixture of academic and non-academic methods, and it has led to the point of concluding that experimental research can and should help victims of sexual violence to construct stories and positions that are more representative and more nuanced than those often found in the context of e.g. lawsuits and news media.

But what are the impacts of the specific project, you might ask. I know that the research process helped the participants find new ways of living with DSA (see author), but I can't say to which extend there is an effect beyond our group. This is where the hope for change becomes central. As activists, we can rarely prove change as a direct result of our work; instead, activism - and activist research - must maintain the hope for change by making change possible. Mathilde, Amalie and Karen are now taking their co-constructed stories out in the world, to their peers and to the organisations and groups that they interact with in their professional and activist work. Another aspect of activist research is that its dissemination is not on the academic alone and therefore my own activism and advocacy is only a small part of it - this makes its impact stronger, but also harder to trace.

This article too is part of the network of ways that these ideas spread. Therefore, to nourish them further, I wish to propose a "manifesto for writing victimhood". It is my hope that this manifesto will inspire future work on victimhood in the context of DSA and beyond; it is my hope that if we - activists, academics, peers and citizens - listen to people as they shape their own becoming as victims (and survivors), we will indeed change to world. 
I WILL LISTEN TO VICTIMS

I WILL NOT FORCE VICTIMHOOD, OR A SPECIFIC KIND OF VICTIMHOOD, ON ANYONE I RESPECT THE COMPLEXITY OF ASSAULT EXPERIENCES, even when they don't fit into my political and theoretical agendas

\section{AIM TO DEVELOP PROGRESSIVE METHODOLOGIES}

I WILL SUPPORT VICTIMS IN FINDING THEIR OWN VOICES by introducing creative and participatory practises

I ENGAGE IN ALTERNATIVE KNOWLEDGE

CONSTRUCTION through experimental

methodologies

I ACKNOWLEDGE THAT INSISTING ON ALTER-

NATIVE TRUTHS IS A VULNERABLE POSITION

I adhere to an ethics of care
I RESPECT THAT CARE IS RELATIONAL AND
REQUIRES OPEN LISTENING

\section{VALUE, BELIEVE IN AND WORK TOWARDS CHANGE}

I KEEP THE HOPE FOR CHANGE CENTRAL and I aim to develop methodologies that make change possible

I BELIEVE IN THE IMPORTANCE OF INDIVIDUAL SURVIVOR STORIES AS PART OF A COLLECTIVE STRUGGLE, and I take responsibility for the ways my work becomes part of this struggle

\section{FIGHT FOR A WORLD WHERE VICTIMS ARE LISTENED TO AND DO NOT HAVE TO CHOOSE BETWEEN DIGNITY AND JUSTICE}

\section{References}

Bell, J., Cheney, G., Hoots, C., Kohrman, E., Schubert, J., Stidham, L., \& Traynor, S. 2004. Comparative similarities and differences between action research, participative research and participatory action research. Critical Inquery, Summer 04, Antioch University Seattle.

Bellacasa, M. P. d. I. 2017. Matters of care : speculative ethics in more than human worlds. Minneapolis: University of Minnesota Press.

Bergold, J., \& Thomas, S. 2012. Participatory Research Methods: A Methodological Approach in Motion. Historical Social Research / Historische Sozialforschung, 37(4), 191-222. doi:10.2307/41756482

Blackman, L. 2012. Listening to Voices: An Ethics of Entanglement. Studies in Qualitative Methodology, 12, 173-188. doi:10.1108/S1042-3192(2012)0000012012

Bolton, G. 2008. "Writing is a way of saying things I can't say"--therapeutic creative writing: a qualitative study of its value to people with cancer cared for in cancer and palliative healthcare. Medical humanities, 34(1), 40-46. doi:10.1136/jmh.2007.000255

Borg, M., Karlsson, B., Kim, H. S., \& McCormack, B. 2012. Opening up for Many Voices in Knowledge Construction. Forum: Qualitative Social Research, 13(1), Art. 1.

Colvin, C. 2019. Traumatic Storytelling and Memory in Post-Apartheid South Africa: Performing Signs of Injury. New York \& London: Routledge.

Davies, B. 2014. Listening to children : being and becoming. Abingdon: Routledge.

Driscoll, C. 2016. Nowhere to Go, Nothing to Do - Place, Desire, and Country Girlhood. In C. Mitchell \& C. Rentschler (Eds.), Girlhood and the Politics of Place (pp. 51-67): Berghahn Books.

Gilligan, C. 1982. In a Different Voice: Psychological theory and women's development (1993 ed.). Cambridge: Harvard Univeristy Press.

Gilligan, C. 2014. Moral Injury and the Ethics of Care: Reframing the Conversation about Differences. Journal of Social Philosophy, 45(1), 89-106. doi:10.1111/josp.12050 
Hale, C. R. 2006. Activist Research v. Cultural Critique: Indigenous Land Rights and the Contradictions of Politically Engaged Anthropology. Cultural Anthropology, 21(1), 96-120. doi:10.1525/can.2006.21.1.96

Held, V. 2014. The Ethics of Care as Normative Guidance: Comment on Gilligan. Journal of Social Philosophy, 45(1), 107-115. doi:10.1111/josp.12051

Hickey-Moody, A. 2013. Youth, arts and education : reassembling subjectivity through affect. Abingdon: Routledge.

Holten, E. 2014. SAMTYKKE. Friktion - Magazin for køn, krop og kultur [Online]. [Accessed May 2020] Available from https://friktionmagasin.dk/samtykke-14841780be52

Hope, S. 2016. Bursting paradigms: a colour wheel of practice-research. Cultural Trends, 25(2), 74-86. doi: $10.1080 / 09548963.2016 .1171511$

Jensen, C. N., \& Ilsøe, T. M. (2018). Advokat for pige i sexvideo: Hun kan aldrig få et almindeligt liv [Online]. [Accessed May 2020] Retrieved from https://www.dr.dk/nyheder/indland/advokat-pige-i-sexvideo-hun-kan-aldrig-faa-et-almindeligt-liv

Koirala-Azad, S., \& Fuentes, E. 2009. Introduction: Activist Scholarship - Possibilities and Constraints of Participatory Action Research. Social Justice, 36(4 (118)), 1-5.

Lamb, S., \& Peterson, Z. 2012. Adolescent Girls' Sexual Empowerment: Two Feminists Explore the Concept. Sex Roles, 66(11), 703-712. doi:10.1007/s11199-011-9995-3

Lezaun, J., Marres, N., \& Tironi, M. 2016. Experiments in Participation. In C. Miller, L. Smith-Doerr, U. Felt, \& R. Fouche (Eds.), The Handbook of Science and Technology Studies (Vol. 4). Cambridge: MIT Press.

Lind, H. 2019. The mood of writerly reading. New Writing, 1-15. doi:10.1080/14790726.2019.1601236

Llambías, P. 2015. Skrivning for begyndere : om skønlitterær skrivekunst for begyndere - en personlig refleksion (1. ed.). Copenhagen: Gyldendal.

Llambías, P. 2017. Der er ingen forskel på at undervise mennesker med kræft og mennesker uden kræft i skrivekunst. In A. J. Rasmussen (Ed.), Læse, skrive og hele - Perspektiver på narrativ medicin (pp. 5156). Odense: Syddansk Universitetsforlag.

McNichol, K. 2016. Who Am I? Writing to Find Myself. Journal of Arts and Humanities, 5(9), 36-40. doi: 10.18533/journal.v5i9.990.

Mosse, D. 2001. 'People's Knowledge', Participation and Patronage: Operations and Representations in Rural Development. In B. Cooke \& U. Kothari (Eds.), Participation: The New Tyranny? (pp. 16-35). London: Zed Books.

Naples, N. A. 2003. Feminism and method : ethnography, discourse analysis, and activist research. New York: Routledge.

Pennebaker, J. 1990. Opening up : the healing power of expressing emotions (1997 ed.). New York: Guilford Press.

Phelan, S. K., \& Kinsella, E. A. 2013. Picture This ... Safety, Dignity, and Voice-Ethical Research With Children : Practical Considerations for the Reflexive Researcher. Qualitative Inquiry, 19(2), 81-90. doi:10.1177/1077800412462987

Reason, P., \& Bradbury, H. 2008. Introduction. In P. Reason \& H. Bradbury (Eds.), The SAGE Handbook of Action Research: Participative Inquiry and Practice (2nd ed., pp. 1-10). London, Thousand Oaks, New Delhi, Singapore: SAGE.

Reid, C., \& Frisby, W. 2008. Continuing the journey: articulating dimensionsof feminist participatory action research (FPAR). In P. Reason \& H. Bradbury (Eds.), The SAGE Handbook of Action Research: Participative Inquiry and Practice (2nd ed., pp. 93-105). London, Thousand Oaks, New Delhi, Singapore: SAGE.

Sommerand, M. 2017. Børnepsykolog: »Det er ikke synd for dem, når de kommer og er kede af, at deres nøgenbilleder er blevet delt « [Online]. Berlingske. Feb. $6^{\text {th }}$. [Accessed May 2020]. Retrieved from https:// www.berlingske.dk/samfund/boernepsykolog-det-er-ikke-synd-for-dem-naar-de-kommer-og-er-kede-afat-deres 
Staunæs, D. 2016. Notes on inventive methodologies and affirmative critiques of an affective edu-future. Research in Education, 96(1), 62-70. doi:10.1177/0034523716664580

Staunæs, D., \& Kofoed, J. 2015a. Hesitancy as ethics. Reconceptualizing Educational Research Methodology, 6(1), 24-39.

Staunæs, D., \& Kofoed, J. 2015b. Producing curious affects: visual methodology as an affecting and conflictual wunderkammer. International Journal of Qualitative Studies in Education, 28(10), 1229-1248. doi :10.1080/09518398.2014.975296

Steenberg, M., \& Ladegaard, N. 2017. Guidet fælleslæsning: Litterær-æstetisk sundhedsfremme. In A. Jensen (Ed.), Kultur og sunhed - en antologi (pp. 175-190). Aarhus: Turbine.

Søndergaard, D. M. 2008. Offerpositionens dilemmaer. Om undvigelse af offerpositionering i forbindelse med mobning og anden relation aggresion. In K. Lützen \& A. K. Nielsen (Eds.), På Kant med Historien: Studier i køn, videnskab og lidenskab tilegnet Bente Rosenbeck på hendes 60-årsdag (pp. 160-194). Copenhagen: Museum Tusculanums Forlag.

Thorhauge, A. M., Demant, J., \& Krogager, S. S. 2020. Intimacy and visual communication in social media. Mediekultur: Journal of media and communication research, 36(67), 1-5. doi:10.7146/mediekultur. v36i67.118198

Tronto, J. C. 1994. Moral boundaries : a political argument for an ethic of care (Repr. ed.). New York: Routledge.

Vestergaard, N., \& Jensen, C. N. 2019. Advokat sidder med 50 sager om digitale krænkelser: Sociale medier bør stilles til ansvar [Online]. [Accsessed May 2020] Retrieved from https://www.dr.dk/nyheder/ indland/advokat-sidder-med-50-sager-om-digitale-kraenkelser-sociale-medier-boer-stilles-til

Zola Christensen, R. 2005. Manual til skrivekunsten. Copenhagen: Gyldendal.

Zwisler, A.-D. O., Rasmussen, A. J., Hellum, R., Tofte, J., Hansen, H. P., Gejl, T., . . Mai, A.-M. 2017. Skriveværksted - Skrivning som innovativ indsats i rehabilitering og palliation. Notat 6. REHPA 